\title{
Effects of Silver Nanocolloid and Copper Oxide (I) on HSP70 Expression and GST Activity in the Caspian Kutum
}

\author{
Razieh Amani ${ }^{1}$, Behrooz Heidari ${ }^{2, *}\left(\mathbb{D}\right.$, Hosein Ghafoori ${ }^{1}$, Abdolmajid Valipour ${ }^{1}$ \\ ${ }^{1}$ University of Guilan, Department of Biology, Faculty of Science, Rasht, Iran. \\ ${ }^{2}$ University of Guilan, Basin Research Center, Department of Marine Sciences, Rasht, Iran.
}

\section{How to cite}

Amani, A., Heidari, B., Ghafoori, H., Valipur, A., I. (2022). Effects of silver nanocolloid and copper oxide (I) on HSP70 expression and GST activity in the Caspian kutum. Turkish Journal of Fisheries and Aquatic Sciences, 22(6), TRJFAS19548. http://doi.org/10.4194/TRJFAS19548

\section{Article History}

Received 25 March 2021

Accepted 02 February 2022

First Online 03 February 2022

\section{Corresponding Author}

Tel.: +981333243630

E-mail: Bheidari@guilan.ac.ir and

Behrooz1072@yahoo.com

\section{Keywords}

Nanoparticles

Stress

Caspian kutum

HSP

GST

\section{Introduction}

The possible danger of nanomaterials to the aquatic environment has drawn attention because of their common usage in industry, medicine, and aquaculture (Fei et al., 2009). Silver nanoparticles (AgNPs) are increasingly used in medicine, healthcare products, food production, household hygiene, and other industrial purposes due to their unique physical and biological properties. These include optical, electrical, and thermal conductivity as well as bactericidal effects (Lee et al., 2012; Luthuli, 2012). Recent studies have shown that silver nanoparticles can interact with macromolecules like proteins, altering the mitochondrial functionality as well as modulating levels and activity of reactive oxygen species (ROS) (Liu, 2006).
Copper $(\mathrm{I})$ oxide $\left(\mathrm{Cu}_{2} \mathrm{O}\right)$ is a red-colored inorganic compound with a cubic structure that possesses both semiconducting as well as antimicrobial properties (Abdel-Khalek et al., 2015). Cuprous oxide is commonly used as a pigment, a fungicide, and an antifouling compound in the production of anti-corrosive paints for marine purposes (Kiaune and Singhasemanon, 2011). The most important copper toxicity pathways include inhibiting ATP pumps, ion channels and enzymes; and inducing ROS synthesis in organisms (Kiaune and Singhasemanon, 2011).

Changes in biochemical status are usually the first detectable response to environmental disorders and stress (Safari et al., 2014). Heat shock proteins (HSPs) are an evolutionary family of conservative and commonly occurring chaperone proteins in eukaryotic 
organisms. Their expression is quickly and continuously modulated in response to metabolic changes, a fundamental mechanism protecting proteins from numerous shocks (Yamashita et al., 2010). Based on their molecular weight, HSPs are divided into three main groups that comprise different families, i.e., (1) macromolecular proteins $(75-110 \mathrm{kDa})$, which include families HSP90/100/110, (2) medium-molecular proteins (47-78 kDa), which include families HSP47/60/70 and (3) small heat shock proteins (sHSP), that comprise molecular mass proteins of $8.5-43 \mathrm{kDa}$ (Luthuli, 2012). One of the largest families and most studied stress-related proteins distributed throughout cells, are HSP families HSP70 and HSP90 (Jing et al., 2013; Mohanty et al., 2018; Sarkar and Roy, 2017). The biological activities of HSPs mainly include facilitating the synthesis and/or folding of proteins in the cell. In addition, HSPs play an important role in the production, secretion, transport, and degradation of proteins, particularly with regard to activity modulation of transcription factors and protein kinases (Abdolhay et al., 2011; Heredia-Middleton et al., 2008; Whitley et al., 1999). Depending on the degree of stress, the expression level of HSPs is subjected to significant and continuous changes, playing an essential role in maintaining the cell's homeostasis. Consequently, the increase and accumulation of HSPs protects cells from stress and ensures cell survival (Safari et al., 2014; Zhang and Zuiderweg, 2004).

Changes in the activity of antioxidant enzymes in aquatic organisms can be considered a potential indicator of stressful conditions. Glutathione Stransferase (GSTs) enzymes are a large family of dimer proteins that are found in all aerobic organisms and are currently known as a major detoxification factor. The GST family is divided into three main subfamilies, namely: cytosolic, mitochondrial, and microsomal, which can constitute up to $10 \%$ of the cytosolic protein in mammalian organs (Afifi et al., 2016; Rudneva et al., 2010). The main function of GST is to catalyze the conjugation of reduced glutathione (GSH) tripeptide with internal and external toxic xenobiotics and, subsequently, converting them and/or their metabolites into hydrophilic compounds that can be easily eliminated from the cell (Carvalho-Neta and Abreu-Silva, 2013; Habig et al., 1974; Zhang et al., 2012).

The Caspian kutum, Rutilus kutum, is a species of the cyprinid family inhabiting brackish waters of the Caspian Sea and its freshwater tributaries (Gharedaashi et al., 2013). The Caspian kutum is migratory and endemic to the Caspian Sea. The Caspian kutum represents a very common and one of the most economically important teleost fishes of Iranian fisheries (Heidari et al., 2009).

To this date, several studies have been carried out on changes in the expression levels of the HSP70 gene under the influence of various nanoparticles in selected aquatic organisms, such as Persian sturgeon (Acipenser persicus) (Safari et al., 2014), rainbow trout
(Oncorhynchus mykiss) (Ceyhun et al., 2010; Feng et al., 2003), common carp (Cyprinus carpio) (Jiang et al., 2016); yellow perch (Perca flavescens) (Pierron et al., 2009) and Japanese medaka (Oryzias latipes) (Chae et al., 2009). Moreover, some studies have been conducted on the measurement of GST in aquatic animals, namely: marine catfish (Arius arius) (Mani et al., 2014), Pemecou sea catfish (Sciades herzhergii) (Carvalho-Neta and Abreu-Silva, 2013); brown trout (Salmo trutta) (Almli et al., 2002), Nile tilapia (Oreochromis niloticus) (Oruç and Üner, 2000), Brycon caphalus (Monteiro et al., 2009) and the other Black Sea teleosts (Rudneva et al., 2010).

Today, the use of nanoparticles and their entry into the aquatic ecosystem is a growing trend. Concentrations of copper (I) oxide and silver nanocolloid nanoparticles have not been measured in the Caspian Sea and its basin; although concentrations of different heavy metals including copper and silver were measured in the Caspian sea by (Pakzad et al., 2016; Raeisi et al., 2014). This study aimed to investigate the effects of copper (I) oxide and silver nanocolloid nanoparticles on expression levels of HSP70 genes in the liver and GST activity in the gill and serum of the Caspian kutum.

\section{Materials and Methods}

\section{Fish}

The Caspian kutum fry ( $N$ 240) with an average weight of $17.1 \pm 3.6 \mathrm{~g}$ obtained from the Fish Rearing, Propagation and Restocking Center of Dr. Yousefpouri (Rasht, Guilan Province, Iran). The fish were kept in a fiberglass tank for 7 days in a volume of 1000 liters of

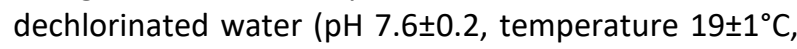
oxygenation $7.4 \pm 0.1 \mathrm{mg} / \mathrm{L})$ without a re-circulation system. The fish were fed approximately $1 \%$ of their body weight two times a day during the experiment with the feeding powder purchased from Isfahan Mokammel Co. (Isfahan, Iran).

\section{Silver Nanocolloid}

\section{Preparation of the Nanocolloid}

Silver nanocolloid was purchased from Nano Nasb Pars (Tehran, Iran) with a concentration of $4000 \mathrm{mg} / \mathrm{L}$. The silver colloid nanoparticles were spherical, $16.6 \mathrm{~nm}$ in diameter, and dark brown in color.

\section{Determination of $L C_{50}$ Concentration}

To determine the $\mathrm{LC}_{50}, 10$ fish (with 3 replicates) were transferred to glass aquaria (volume of $80 \mathrm{~L}$ ) and kept under constant conditions (photoperiod 12L12D; water hardness $263 \pm 4 \mathrm{ppm}$; temperature $19 \pm 1^{\circ} \mathrm{C}$ and $\mathrm{pH}$ $7.6 \pm 0.2$ ) for 96 hours. After the acclimatization period, different concentrations of silver nanocolloid were 
tested to determine its $\mathrm{LC}_{50}$ concentration level. As a result, the concentration of $0.25 \mathrm{mg} / \mathrm{L}$ was determined as LC5096h for silver colloid nanoparticles.

\section{Copper (I) Oxide Nanoparticle $\left(\mathrm{Cu}_{2} \mathrm{O}\right)$}

\section{Preparation of $\mathrm{Cu}_{2} \mathrm{O}$}

Based on the protocol described by Bai et al. (2012), $\mathrm{Cu}_{2} \mathrm{O}$ was synthesized in the Marine Biology Laboratory at the University of Guilan (Bai et al., 2012). $0.05 \mathrm{~g}$ of copper (II) acetate and $0.125 \mathrm{~g}$ of PVP (Poly Vinyl Pyrolidon) were dissolved in $100 \mathrm{ml}$ of deionized water to make the aqueous solution. Then, $20 \mathrm{ml}$ of 0.25 $M$ sodium hydroxide $(\mathrm{NaOH})$ water solution was added drop by drop to the starting solution under intense shaking. Next, $15 \mathrm{ml}$ of $0.05 \mathrm{M}$ ascorbic acid water solution was slowly added to the resulted solution under the same conditions. The color of the mixture changed from blue through green to orange after 30 minutes of shaking. In the end, the obtained solution was centrifuged for 15 minutes at $4000 \mathrm{rpm}$ and the separated orange deposits were dried in an oven.

\section{X-ray Diffraction Analysis}

X-ray diffraction (XRD) was used to determine the type of synthesized material $\left(\mathrm{Cu}_{2} \mathrm{O}\right)$, as well as the phase and its crystalline properties. For this purpose, a sample of synthesized nanoparticles $(0.1 \mathrm{~g})$ was sent to Beam Gostar Taban Research Laboratory located in Tehran, Iran for the specified analysis.

\section{Determination of $L C_{50}$ Concentration}

Based on (Mazarei et al., 2015), a concentration of $1.7 \mathrm{mg} / \mathrm{L}$ of $\mathrm{Cu}_{2} \mathrm{O}$ was considered as $\mathrm{LC}_{50}$. The specific procedure was the same as for silver colloid nanoparticles.

\section{Treatments}

The following concentrations of silver nanocolloid were selected for treatments used in the present study: $0.0125,0.0875$, and $0.175 \mathrm{mg} / \mathrm{L}$, which consist of 5,35 , and $70 \%$ of determined $\mathrm{LC}_{50}$ concentration, respectively. For $\mathrm{Cu}_{2} \mathrm{O}$, the applied concentrations were as follows: 0.425 and $0.850 \mathrm{mg} / \mathrm{L}$, which consist of 25 and $50 \%$ of determined $\mathrm{LC}_{50}$ concentrations, respectively. A control group comprised of fish that were not exposed to any treatment.

In total, the experiments were carried out in six groups, i.e., 3 groups for silver nanocolloid, two for $\mathrm{Cu}_{2} \mathrm{O}$, and one control group. Each experimental group was carried out in triplicates that give a total number of 18 tanks used. In general, the number of fish used under each experimental variant was 30, including each replicate (10 fish per tank).

The fish were kept in glass aquariums of 80 liters volume with constant conditions (photoperiod 12L12D; pH 6.6-7.2, Temperature $21 \pm 2^{\circ} \mathrm{C}$; oxygen $7.7 \pm 0.5 \mathrm{mg} / \mathrm{L}$ ). After the adaptation period, feeding was stopped and the experiments commenced in 24 hours. Then, the determined concentrations of silver nanocolloid and $\mathrm{Cu}_{2} \mathrm{O}$ were added to the respective aquaria. Before adding the nanoparticles, the nanoparticles were homogenized by sonication for 5 minutes.

The exposure of fish to the silver colloid and $\mathrm{Cu}_{2} \mathrm{O}$ nanoparticles was continuously carried out for 21 days. To maintain good sanitary conditions of each aquarium during the experiment, the fish were transferred to a fresh aquarium with the same conditions and the same concentration of nanoparticles on every $3^{\text {rd }}$ day of treatment.

\section{Sampling}

The sampling of fish was done randomly on days 7 and 21 of exposure to the nanoparticles used. Blood samples were collected from randomly selected fish within each treatment. To this end, the fish were subjected to anesthesia by transferring to a smaller container of water mixed with clove oil in a dosage of 30 $\mathrm{mg} / \mathrm{L}$ (Neiffer and Stamper, 2009). Then, the fish were placed in a wet cotton cloth and the heparinized syringe with a $23 \mathrm{~g}$ needle was used to collect the blood samples via vertical way through the spine after the anterior fin. $0.2 \mathrm{ml}$ of drawn blood was centrifuged at $4^{\circ} \mathrm{C}$ and 4000 $\mathrm{rpm}$. The separated serum was stored at $-70^{\circ} \mathrm{C}$ in the freezer. Next, new specimens were dissected and the gill and liver tissues were collected. For euthanasia, the fish were first anesthetized with benzocaine and then frozen (Underwood and Anthony, 2013). The samples of gill were mixed with sodium phosphate buffer $(\mathrm{pH} \mathrm{6.5)}$ at a 1:5 ratio and then centrifuged (Centurion Scientific, UK) at $6000 \mathrm{rpm}$ and $4^{\circ} \mathrm{C}$ for 10 minutes. The homogenized extract was finally transferred to a freezer and stored at $-70^{\circ} \mathrm{C}$.

\section{RNA Extraction}

The Trizol method was used to extract RNA. Liver tissue (50-100 $\mathrm{mg}$ ) was homogenized in liquid nitrogen and added to a $1 \mathrm{ml}$ solution of Trizol and incubated for 5 minutes at room temperature. Then, $400 \mu$ l of chloroform was added, shortly vortexed, and left at room temperature for 2 to 3 minutes. Next, the solution was centrifuged at $10,000 \mathrm{rpm}$ for 15 minutes at $4^{\circ} \mathrm{C}$ and the supernatant containing RNA was slowly separated and transferred to a new microtube. Isopropanol (500 $\mu l)$ was then added to the microtube containing RNA and stored at room temperature for 10 minutes. The precipitate was separated from the isopropanol by centrifugation $\left(10,000 \mathrm{rpm}\right.$ for 10 minutes at $\left.4^{\circ} \mathrm{C}\right)$. After that, $1000 \mu \mathrm{l}$ of $75 \%$ ethanol was added to the precipitate and centrifuged for 5 minutes $(7,800 \mathrm{rpm}$ at $\left.4^{\circ} \mathrm{C}\right)$. The isolated RNA was then stored at $-70^{\circ} \mathrm{C}$ until further analyses. 


\section{Complementary DNA Synthesis}

Before complementary DNA synthesis, the isolated RNA was subjected to the RNase-free DNase I (Thermo Fisher Scientific, USA) to remove the remnant DNA present in the RNA samples. For this end, $2 \mu \mathrm{l}$ DNase and $2 \mu \mathrm{l}$ DNase buffer was added to $16 \mu$ l extracted RNA and incubated for 30 minutes at $37^{\circ} \mathrm{C}$. Then, $1 \mu$ EDTA was added and again incubated at $65^{\circ} \mathrm{C}$ for 10 minutes. Finally, $4 \mu \mathrm{l}$ of the sample was collected and stored at $70^{\circ} \mathrm{C}$. The NanoDrop spectrophotometer (Thermo Fisher Scientific, USA) was used to determine the quality and quantity of resulted RNA at absorption 260 and $280 \mathrm{~nm}$.

The BIOFACT kit (South Korea) was used to synthesize cDNA, carried out in two steps as recommended in the manufacturer's protocol. First, 50 $\mu \mathrm{M}$ of Oligo dT Primer $(1 \mu \mathrm{l}), 10 \mathrm{mM}$ of each dNTP and 2 $\mu$ l of template RNA $(1 \mu \mathrm{g})$ were mixed, filled to $10 \mu \mathrm{l}$ with diethylpyro- carbonate (DEPC) water and was incubated for $5 \mathrm{~min}$ at $65{ }^{\circ} \mathrm{C}$; then cooled immediately on ice. Afterward, $4 \mu$ l of $5 X$ Prime Script Buffer, $0.5 \mu$ l RNase Inhibitor $(40 \mathrm{U} / \mu \mathrm{l}), 1 \mu \mathrm{l}$ Prime Script RTase $(200 \mathrm{U} / \mu \mathrm{l})$ and $5.5 \mu \mathrm{L}$ DEPC treated water was added to the above mixture, and the mix was incubated for 30 minutes at $50^{\circ} \mathrm{C}$. In the end, it was immediately incubated at $95^{\circ} \mathrm{C}$ for 10 minutes and kept at $-70^{\circ} \mathrm{C}$ for further analysis.

\section{Polymerase Chain Reaction (PCR)}

For PCR primer design, the sequence of the Caspian kutum HSP70 nucleotide was searched in the NCBI database (Accession number: KT380686) and the FASTA aligned sequences were transferred to Gene Runner software (Version 6.5.52 x64 Beta). The maximum specificity of designed primers was validated with an online primer blast (Table 1). PCR reaction was carried out within a $20 \mu \mathrm{l}$ reaction mix that consisted of $100 \mathrm{ng}$ of liver tissue synthesized CDNA, $2 \mu$ of PCR buffer, $1.75 \mu \mathrm{l} \mathrm{MgCl} 2,1.2 \mu \mathrm{ldNTP}, 0.2 \mu \mathrm{l} \mathrm{Taq}$ polymerase, and 0.2 $\mu \mathrm{M}$ of each primer. The desired volume of the reaction mix was obtained by adding nuclease-free water. The PCR program comprised the following steps: initial denaturation at $95^{\circ} \mathrm{C}$ for 5 minutes followed by 35 cycles of 15 seconds at $95^{\circ} \mathrm{C}$ (denaturation), 30 seconds at $60^{\circ} \mathrm{C}$ (annealing), 40 seconds at $72^{\circ} \mathrm{C}$ (extension). In the end, the final extension step at $72^{\circ} \mathrm{C}$ for 5 minutes was applied. The target PCR products were analyzed by electrophoresis in a $2 \%$ agarose gel stained with safestain.

\section{Glutathione S-Transferase (GST) Assay}

The assay method was based on the use of substrate containing 1-chloro, 2-nitrobenzene (CDNB) and reduced glutathione (GSH) (Habig et al., 1974). Ten microliters of each substrate at a concentration of $100 \mu \mathrm{M}$ were mixed with $25 \mu$ l of samples (gill and serum) and diluted to a volume of $1000 \mu$ l by adding sodium phosphate buffer $(\mathrm{pH}$ 6.5). The absorbance of the samples was read at $340 \mathrm{~nm}$ for 5 minutes using a spectrophotometer (lab Unlimited, UK).

\section{Statistical Analysis}

The data were analyzed using SPSS version 19 in Windows 10. Kolmogorov-Smirnov test was used to measure the normality of the data. In the case of normal data, one-way ANOVA with Duncan's post hoc test was used to evaluate the differences between treatments at the confidence level of $95 \%$. Independent T-test was performed to determine the difference between day seven and day twenty of the experiment. In addition, the combined effects of the exposure time and concentration of the nanoparticles were analyzed by two-way ANOVA. All data were expressed in mean \pm SD.

\section{Results}

\section{XRD of Copper (I) Oxide Nano Synthesis}

Analysis of the X-ray diffraction and "the Joint Committee on Powder Diffraction Standards (Jcpbs) file No-77-0199" showed that the synthesized material was the copper (I) oxide $\left(\mathrm{Cu}_{2} \mathrm{O}\right)$ nanoparticle (Figure 1$)$.

\section{Silver Nanocolloid}

\section{Expression of the HSP70 Gene}

The recorded patterns in expression levels of HSP70 were similar both on the $7^{\text {th }}$ and $21^{\text {st }}$ day of experimental exposure on silver nanocolloid ( $r=0.90$, $p<0.05)$. The expression level of HSP70 increased significantly in all treatments compared to the control on the $7^{\text {th }}$ day of exposure $(p<0.05)$ (Figure 2$)$. The highest expression level was reported for the silver nanocolloid concentration at the level of $0.0875 \mathrm{mg} / \mathrm{L}$ and differed significantly from other exposure variants $(p<0.05)$. The applied two-way ANOVA test evidenced the significant influence of exposure time (days) and tested concentrations on observed levels of HSP70 gene expression $(p<0.05)$. According to the independent $T$ test, the observed differences in HSP70 gene expression on the $7^{\text {th }}$ and $21^{\text {st }}$ day of exposure under all concentrations tested were statistically significant $(0.0125,0.0875$, and $0.125 \mathrm{mg} / \mathrm{L})(\mathrm{p}<0.05)$.

\section{Changes in GST Activity of the Gills}

According to the obtained results, a specific trend toward increased GST activity in gill tissue of the fish treated by the silver nanocolloid in the concentration of $0.175 \mathrm{mg} / \mathrm{L}$ compared to the control group at both the $7^{\text {th }}$ and $21^{\text {st }}$ day of exposure $(p<0.05)$ (Figure 3 ) was observed. The maximum GST activity was recorded at $0.0125 \mathrm{mg} / \mathrm{L}$ concentration on the $7^{\text {th }}$ day of experimental exposure. Based on two-way ANOVA, the interaction of days of exposure and different 
concentration had no significant effect on GST activity ( $p>0.05$ ) but there were significant differences in GST activity between different concentrations $(p<0.05)$ and between days of exposure $(p>0.073)$. According to the independent T-test, a significant difference was observed in GST activity under the concentration of $0.0125 \mathrm{mg} / \mathrm{L}$ between the $7^{\text {th }}$ and $21^{\text {st }}$ day of experimental exposure $(p<0.05)$.

\section{Changes in GST Enzyme of the Serum}

The performed analysis on GST in the serum showed an increase in activity under the $0.175 \mathrm{mg} / \mathrm{L}$ concentration of silver nanocolloid, both on the $7^{\text {th }}$ and $21^{\text {st }}$ day of exposure $(p<0.05)$ (Figure 4$)$. Based on twoway ANOVA there were no significant differences in GST activity between each day of exposure $(p>0.073)$ and their interaction (days of exposure and different concentration) ( $p>0.05)$. In turn, the significant differences in GST activity were recorded between different concentration variants $(p<0.05)$. In addition, there was a significant correlation in variations of GST activity between the $7^{\text {th }}$ and $21^{\text {st }}$ day of exposure at $0.0125 \mathrm{mg} / \mathrm{L}$ concentration $(r=0.89 ; p<0.05)$. The maximum GST activity was recorded at $0.175 \mathrm{mg} / \mathrm{L}$ of silver nanocolloid. According to the independent T-test, a significant difference was also observed in GST activity at a concentration of $0.0125 \mathrm{mg} / \mathrm{L}$ between the $7^{\text {th }}$ and $21^{\text {st }}$ day of exposure $(p<0.05)$.

\section{Copper (I) oxide (Cu2O)}

\section{HSP70 gene expression on $7^{\text {th }}$ and $21^{\text {st }}$ day}

An increase in HSP70 gene expression was observed at different concentrations of copper (I) oxide

Table 1. Primer sequences of HSP70 genes of the Caspian kutum.

\begin{tabular}{lcc}
\hline Gene & Forward & Reverse \\
\hline HSP70 & AGTTGTCACAGTTCCTGCC & GTCTCTCAGGGCTTTCTCC \\
\hline
\end{tabular}

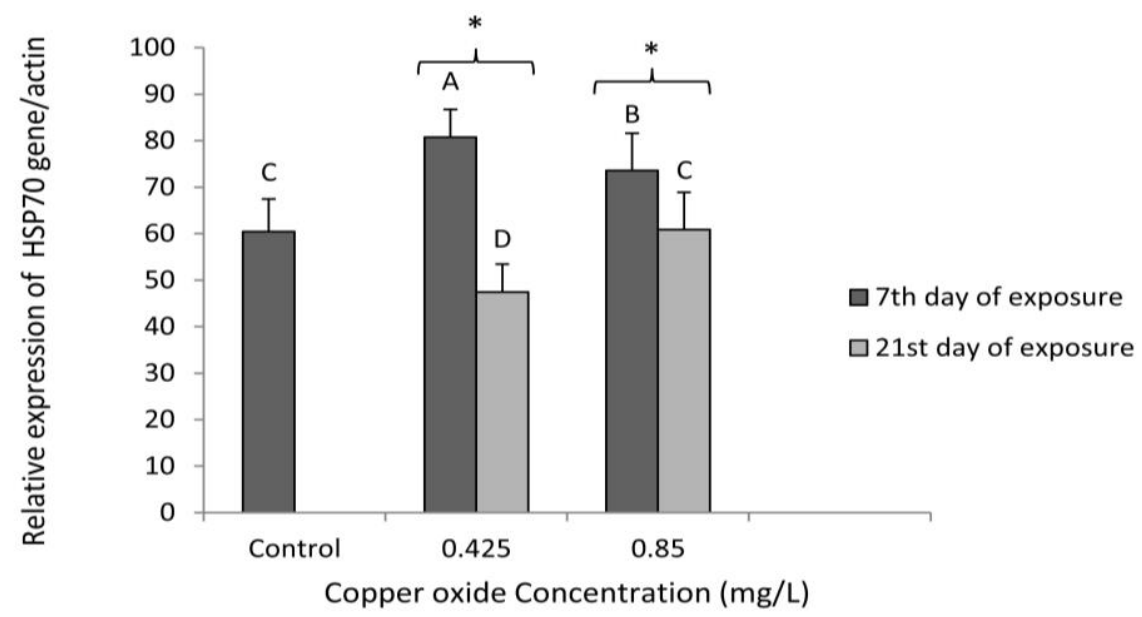

Figure 1. XRD analysis of synthesized copper (I) oxide nanoparticle.

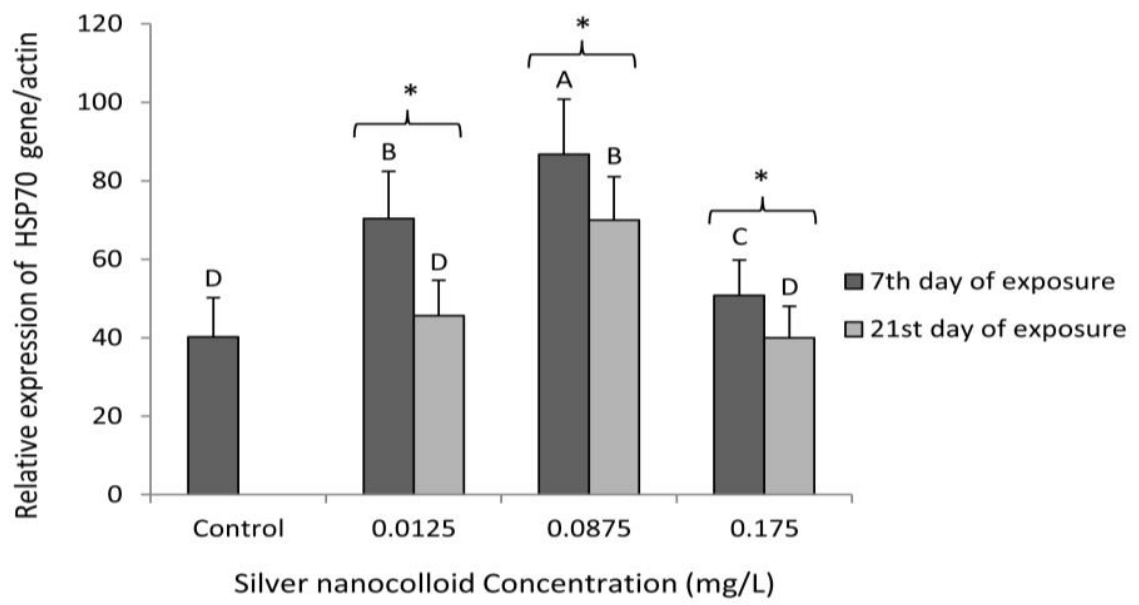

Figure 2. HSP70 gene expression in the liver of Caspian kutum exposed to different concentrations of silver nanocolloid. The letters above columns are showing significantly different based on one-way ANOVA and the symbols, *, are showing a significant difference between the $7^{\text {th }}$ and $21^{\text {st }}$ day of exposure in each concentration based on independent T-test $(p<0.05)$. 
nanoparticles $(0.425$ and $0.85 \mathrm{mg} / \mathrm{L})$ compared to the control on the $7^{\text {th }}$ day of exposure $(p<0.05)$ (Figure 5$)$. On the $21^{\text {st }}$ day of exposure, the highest level of HSP70 was recorded at $0.85 \mathrm{mg} / \mathrm{L}(\mathrm{p}>0.05)$. Gene expression of HSP70 was significantly higher in all treatments on the $7^{\text {th }}$ day of exposure compared to the $21^{\text {st }}$ day of exposure $(p<0.05)$. Based on two-way ANOVA, the interaction between days of exposure and different concentration had a significant effect on HSP70 gene expression $(p<0.05)$. According to the independent Ttest, a significant difference was observed in HSP70 gene expression in both concentrations of copper (I) oxide nanoparticles $(0.425$ and $0.85 \mathrm{mg} / \mathrm{L})$ on the 7 and 21 days of exposure $(p<0.05)$.

\section{Discussion}

In the present study, changes in HSP70 gene expression in the liver of Caspian kutum fry were significantly increased in all treatment variants compared to the control group on the $7^{\text {th }}$ and $21^{\text {st }}$ days of exposure, which suggests the essential role of the HSP70 gene in reducing shock outcomes caused by exposure on nanomaterials in fish. Contrary to the present study, (Safari et al., 2014) observed a significant decrease in HSP70 expression in Acipenser persicus liver on the $7^{\text {th }}$ day and a significant increment on the $14^{\text {th }}$ day exposure to different concentrations of cadmium chloride. In turn, (Girilal et al., 2015) showed a significant increase in HSP70 gene expression in the liver of Oreochromis niloticus exposed to chemically synthesized silver compound derivatives. In this study, the observed increase in HSP70 expression at 0.0875 $\mathrm{mg} / \mathrm{L}$ following silver nanocolloid exposure at both sampling days compared to the concentration of 0.175 $\mathrm{mg} / \mathrm{L}$ may be due to a reduction of metabolic capacity of the fish due to toxicity (Safari et al., 2014). Moreover, nanoparticles and silver nanocolloid in the aquatic environment can accumulate at high concentrations, reducing the efficiency of their displacement and consequently, leading to adverse interaction and alterations in the metabolism of living organisms (Behra

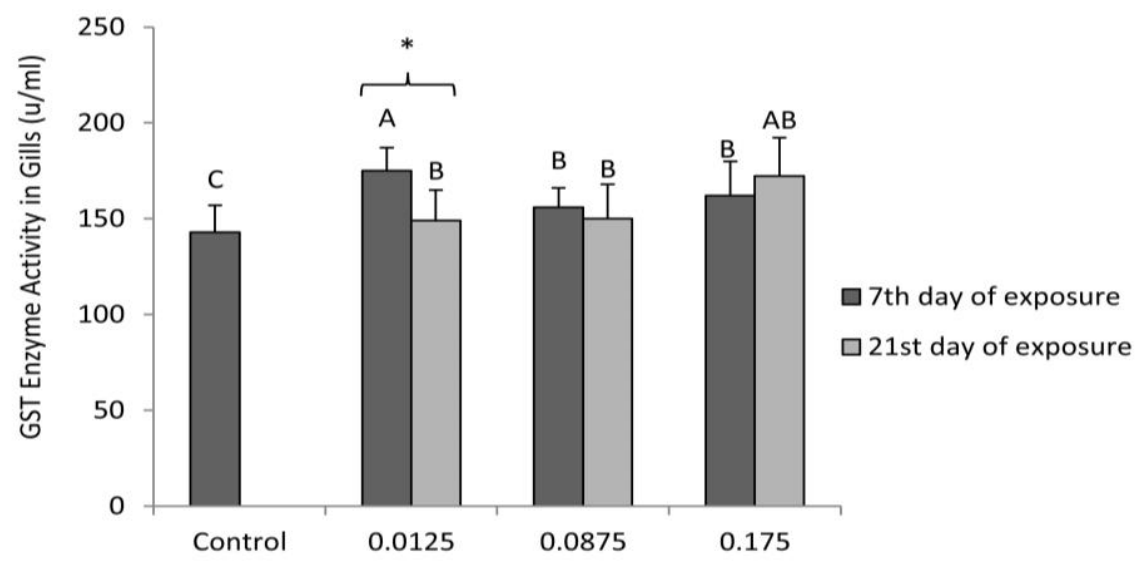

Silver nanocolloid Concentration ( $\mathrm{mg} / \mathrm{L}$ )

Figure 3. GST activity of gills affected by different concentrations of silver nanocolloid on the $7^{\text {th }}$ and $21^{\text {st }}$ days of exposure. The letters above columns are showing significantly different based on one-way ANOVA and the symbols, ${ }^{*}$, are showing a significant difference between the $7^{\text {th }}$ and $21^{\text {st }}$ day of exposure in each concentration based on independent T-test $(p<0.05)$.

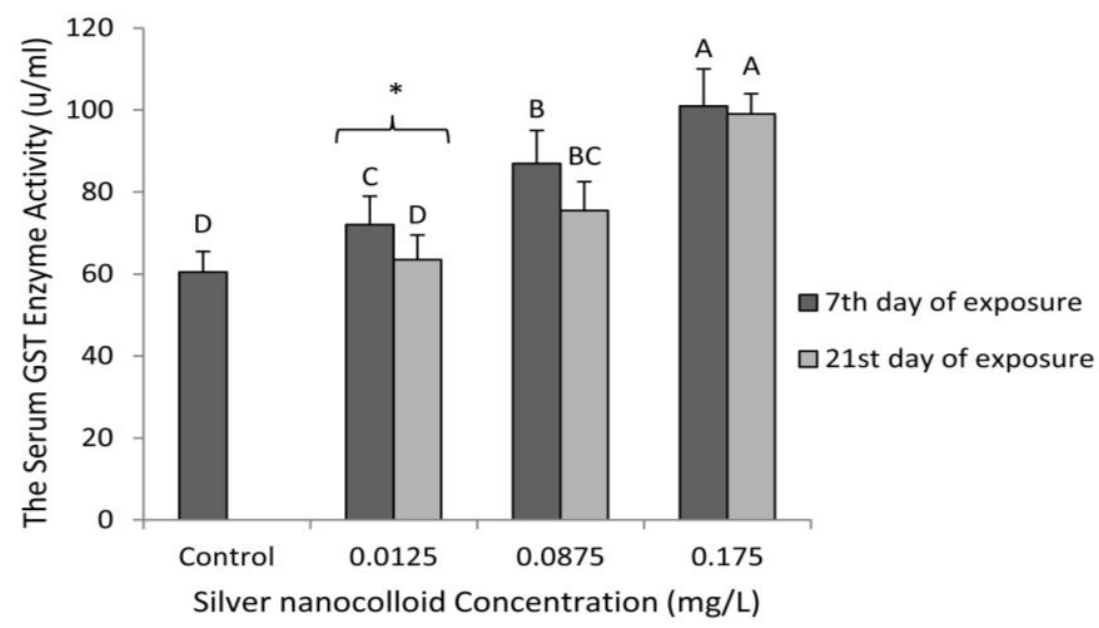

Figure 4. The serum GST activity was affected by different concentrations of silver nanocolloid on the $7^{\text {th }}$ and $21^{\text {st }}$ days of exposure. The letters above columns are showing significantly different based on one-way ANOVA and the symbols, ${ }^{*}$, are showing a significant difference between the $7^{\text {th }}$ and $21^{\text {st }}$ day of exposure in each concentration based on independent $T$-test $(p<0.05)$. 


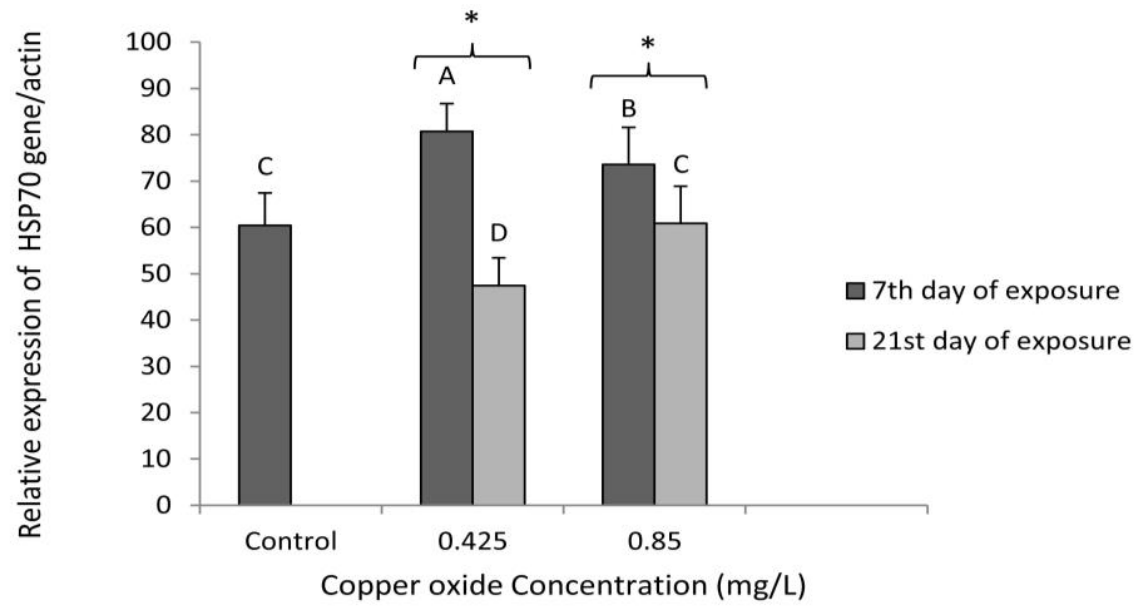

Figure 5. HSP70 gene expression in the liver of Caspian kutum exposed to different concentrations of Cu2O nanoparticle. The letters above columns are showing significantly different based on one-way ANOVA and the symbols, ${ }^{*}$, are showing a significant difference between the $7^{\text {th }}$ and $21^{\text {st }}$ day of exposure in each concentration based on independent T-test $(p<0.05)$.

et al., 2013). Silver nanoparticles in the aqueous medium are capable of inducing apoptosis and ROS that probably caused the increased gene expression of HSP70 in the Caspian kutum's liver, observed in this study.

In the case of copper (I) oxide, the results obtained showed that changes in HSP70 gene expression generally exhibited a significant increase on the $7^{\text {th }}$ day, which subsequently decreased on the $21^{\text {st }}$ day compared to the control group. (Jiang et al., 2016) observed a similar decrease in gene expression in the common carp under simultaneous exposure to cadmium and copper metals, compared to the control. Moreover, the authors observed a significant increase in gene expression at high doses of copper and cadmium after 96 h. (Safari et al., 2014) reported a considerable decrease at different concentrations of endosulfan toxin on the $7^{\text {th }}$ day of exposure and found a significant increase in HSP70 gene expression in Acipenser persicus's liver on the $14^{\text {th }}$ day of treatment. It was evidenced that high levels of copper can cause severe changes in the internal protein system. The process can take place directly by denaturing the proteins or indirectly by producing elevated levels of ROS (Kiaune and Singhasemanon, 2011). The increase of HSP70 expression in the liver may be due to its chaperone function, which plays a vital role in the cellular response process, and it is critical for protecting cells from copperinduced toxicity (Feng et al., 2003). Therefore, it seems probable that the increase in HSP70 levels in the present study may be due to a requirement for the re-folding of denatured proteins and restoring homeostasis in the Caspian kutum. The observed higher expression levels of the HSP70 may also be a secondary after-effect of shock caused by nanoparticles, as heat shock proteins display an evolutionarily-determined high sensitivity to occurring stresses.

A relatively higher increase in liver HSP70 gene expression in all treatments was observed on the $7^{\text {th }}$ day of exposure compared to the $21^{\text {st }}$ day treatment, which was different from the results of time-dependent changes in HSP70 in Iranian sturgeon fry affected by cadmium chloride (Safari et al., 2014). The toxicity of copper nanoparticles inhibits ATP bypass pumps and enzymes, and chronic exposure can affect ATPdependent functions in HSP70 (Kiaune and Singhasemanon, 2011). Therefore, the accumulation of the nanoparticles may be responsible for a lowering expression level of HSP70 during prolonged exposure on the $21^{\text {st }}$ day compared to the $7^{\text {th }}$ day of treatment. It also seems probable that the lower expression on the $21^{\text {st }}$ day of the experiment in the Caspian kutum fry may be a result of acclimatization to stress induced by the nanoparticles.

In the present study, a significant increase in GST was observed in different silver nanocolloid treatments compared to the control. (Lee et al., 2012) found no significant change in GST activity at low concentrations of silver nanoparticles coupled with citrate after 48 hours of exposure in Cyprinus carpio. Moreover, a considerable decrease in GST activity at high concentrations of nanoparticles after 96 hours of exposure was also recorded. (Srikanth et al., 2014) reported a significant time-dependent increase in GST up to 72 hours of exposure to the oxide nanoparticles (IO-NP). Silver nanoparticles can enter the cell during division or endocytosis and as a result, cause disturbances in mitochondrial functionality, leading to oxidative stress through elevated levels of ROS (Afifi et al., 2016). Increased levels of GST activity in gill may be linked with detoxification and cell defense activity, due to its antioxidant effect against oxidative stress caused by metal nanoparticles (Lee et al., 2012). Differences in the activity of antioxidant enzymes are dependent on the species, tissue type and composition of the stressor, its dosage and, exposure time. It is probable that exposure to oxidative conditions due to the presence of silver nanocolloid, increases the GST activity in the gill.

In the present study, a significant increase in GST activity levels was observed in the serum at both the $7^{\text {th }}$ and $21^{\text {st }}$ day of exposure to silver nanocolloid, compared to the control. Aliko et al. (2018) observed a significant 
increase in the GST activity of goldfish's (Carassius auratus) plasma after 96 hours of exposure to manganese compounds (Aliko et al., 2018). GST is found in erythrocytes and plays a role in cell defense against stressful conditions. Increased serum GST in the Caspian kutum fry could directly affect metabolic disorders and erythrocyte injury.

In the present study, a significantly higher increase in GST activity was observed both in gill and serum on the $7^{\text {th }}$ day of exposure, compared to the $21^{\text {st }}$ day. The level of induced GST was differential and mainly depended on tissue type and the nature of the inducer. An increase in GST activity on the $7^{\text {th }}$ day of treatment evidences the role of GST in the antioxidant system and defense against free radicals, most probably taking part in the adaptation process of fish to stressful conditions (Oliveira et al., 2009). It seems that increases in gill and serum GST activity on the $7^{\text {th }}$ day exposure (acute toxicity) in Caspian kutum fry are associated with its antioxidant function, playing a significant role in defense mechanisms against free radicals caused by exposure to silver nanocolloids.

It is probable that the decrease in GST activity in Caspian kutum fry on the $21^{\text {st }}$ day is due to prolonged exposure to silver nanocolloids, which may indicate adaptation to stressful conditions in semi-chronic toxicity.

\section{Conclusion}

In conclusion, it seems that the presence of metal nanoparticles such as silver and copper (I) oxide adversely affects the health of aquatic organisms. Therefore, further studies are needed on the effects of nanoparticles on the expression of health-promoting genes and antioxidant enzymes, which maintain the homeostasis and survival of organisms.

\section{Ethical Statement}

Animal handling and tissue sampling procedures were carried out under the standard principles of laboratory animal care to reduce animal suffering; and the study was approved by the local ethics committee of the Faculty of Science, University of Guilan (reference number 2949436). For euthanasia, the fish were first anesthetized with benzocaine and then frozen (Underwood and Anthony, 2013).

\section{Funding Information}

Not applicable.

\section{Author Contribution}

Razieh Amani prepared equipment and performed the experiments. Behrooz Heidari was the corresponding author, supervisor and designed the experiment and he was in charge of all stages of the project. Hosein Ghafoori was the advisor. AbdolMajid Valipour wrote the manuscript, prepared figures, and tables.

\section{Conflict of Interest}

Ther is no conflict of interest.

\section{Acknowledgements}

We would like to thank marine biology students of Guilan University and Dr. Mahvash Hadavi, indispensable to the successful accomplishment of this article.

\section{References}

Abdel-Khalek, A.A., Kadry, M.A., Badran, S.R., Marie, M.-A.S. (2015). "Comparative toxicity of copper oxide bulk and nano particles in Nile tilapia; Oreochromis niloticus: biochemical and oxidative stress". The Journal of Basic \& Applied Zoology, 72, 43-57.

Abdolhay, H., Daud, S., Ghilkolahi, S.R., Pourkazemi, M., Siraj, S., Satar, M.A. (2011). "Fingerling production and stock enhancement of Mahisefid (Rutilus frisii kutum) lessons for others in the south of Caspian Sea". Reviews in fish biology and fisheries, 21, 247-257.

Afifi, M., Saddick, S., Zinada, O.A.A. (2016). "Toxicity of silver nanoparticles on the brain of Oreochromis niloticus and Tilapia zillii". Saudi journal of biological sciences, 23, 754760.

Aliko, V., Qirjo, M., Sula, E., Morina, V., Faggio, C. (2018). "Antioxidant defense system, immune response and erythron profile modulation in gold fish, Carassius auratus, after acute manganese treatment". Fish \& shellfish immunology, 76, 101-109.

Almli, B., Egaas, E., Christiansen, A., Eklo, O., Lode, O., Källqvist, T. (2002). "Effects of three fungicides alone and in combination on glutathione S-transferase activity (GST) and cytochrome P-450 (CYP 1A1) in the liver and gill of brown trout (Salmo trutta)". Marine environmental research, 54, 237-240.

Bai, Y., Yang, T., Gu, Q., Cheng, G., Zheng, R. (2012). "Shape control mechanism of cuprous oxide nanoparticles in aqueous colloidal solutions". powder technology, 227, 35-42.

Behra, R., Sigg, L., Clift, M.J., Herzog, F., Minghetti, M., Johnston, B., Petri-Fink, A., Rothen-Rutishauser, B. (2013). "Bioavailability of silver nanoparticles and ions: from a chemical and biochemical perspective". Journal of the Royal Society Interface, 10, 20130396.

Carvalho-Neta, R.N., Abreu-Silva, A.L. (2013). "Glutathione STransferase as biomarker in Sciades herzbergii (Siluriformes: Ariidae) for environmental monitoring: the case study of São Marcos Bay, Maranhão, Brazil". Latin American Journal of Aquatic Research, 41, 217-225.

Ceyhun, S.B., Şentürk, M., Ekinci, D., Erdoğan, O., Çiltaş, A., Kocaman, E.M. (2010). "Deltamethrin attenuates antioxidant defense system and induces the expression of heat shock protein 70 in rainbow trout". Comparative Biochemistry and Physiology Part C: Toxicology \& Pharmacology, 152, 215-223.

Chae, Y.J., Pham, C.H., Lee, J., Bae, E., Yi, J., Gu, M.B. (2009). 
"Evaluation of the toxic impact of silver nanoparticles on Japanese medaka (Oryzias latipes)". Aquatic Toxicology, 94, 320-327.

Fei, Q., Xiao, D., Zhang, Z., Huan, Y., Feng, G. (2009). "A novel silica-coated multiwall carbon nanotube with $\mathrm{CdTe}$ quantum dots nanocomposite". Spectrochimica Acta Part A: Molecular and Biomolecular Spectroscopy, 74, 597-601.

Feng, Q., Boone, A.N., Vijayan, M.M. (2003). "Copper impact on heat shock protein 70 expression and apoptosis in rainbow trout hepatocytes". Comparative Biochemistry and Physiology Part C: Toxicology \& Pharmacology, 135, 345-355.

Gharedaashi, E., Nekoubin, H., Imanpoor, M.R., Taghizadeh, V. (2013). "Effect of copper sulfate on the survival and growth performance of Caspian Sea kutum, Rutilus frisii kutum". SpringerPlus, 2, 498.

Girilal, M., Krishnakumar, V., Poornima, P., Fayaz, A.M., Kalaichelvan, P. (2015). "A comparative study on biologically and chemically synthesized silver nanoparticles induced Heat Shock Proteins on fresh water fish Oreochromis niloticus". Chemosphere, 139, 461-468.

Habig, W.H., Pabst, M.J., Jakoby, W.B. (1974). "Glutathione Stransferases the first enzymatic step in mercapturic acid formation". Journal of biological Chemistry, 249, 71307139.

Heidari, B., Shabanipour, N., Savari, A., Yavari, V., Hosseini, N. (2009). "The oocyte development of Kutum, Rutilus frisii kutum, K. with special emphasis on the zona radiata structure". Animal Reproduction, 3, 465-472.

Heredia-Middleton, P., Brunelli, J., Drew, R.E., Thorgaard, G.H. (2008). "Heat shock protein (HSP70) RNA expression differs among rainbow trout (Oncorhynchus mykiss) clonal lines". Comparative Biochemistry and Physiology Part B: Biochemistry and Molecular Biology, 149, 552556.

Jiang, X., Guan, X., Yao, L., Zhang, H., Jin, X., Han, Y. (2016). "Effects of single and joint subacute exposure of copper and cadmium on heat shock proteins in common carp (Cyprinus carpio)". Biological trace element research, 169, 374-381.

Jing, J., Liu, H., Chen, H., Hu, S., Xiao, K., Ma, X. (2013). "Acute effect of copper and cadmium exposure on the expression of heat shock protein 70 in the Cyprinidae fish Tanichthys albonubes". Chemosphere, 91, 1113-1122.

Kiaune, L., Singhasemanon, N. (2011). "Pesticidal copper (I) oxide: environmental fate and aquatic toxicity". Reviews of Environmental Contamination and Toxicology Volume 213. Springer, 1-26.

Lee, B., Duong, C.N., Cho, J., Lee, J., Kim, K., Seo, Y., Kim, P., Choi, K., Yoon, J. (2012). "Toxicity of citrate-capped silver nanoparticles in common carp (Cyprinus carpio)". BioMed Research International, 2012.

Liu, W.-T. (2006). "Nanoparticles and their biological and environmental applications". Journal of bioscience and bioengineering, 102, 1-7.

Luthuli, D.S., 2012. Analysis of the effects of Gold nanoparticles on the functional integrity of select serum proteins and heat shock proteins of mammalian origin.

Mani, R., Meena, B., Valivittan, K., Suresh, A. (2014). "Glutathione-S-Transferase and Catalase activity in different tissues of marine Catfish (Arius arius) on exposure to Cadmium". International Journal of Pharmacy and Pharmaceutical Sciences, 6, 326-332.
Mazarei, S., Sajjadi, M.M., Sourinejad, I., Johari, S.A., Asadi, M. (2015). "Effect of lethal concentration of Nano Silver in Aphanius dispar". Journal of Aquatic Ecology, 4, 115-110.

Mohanty, B.P., Mahanty, A., Mitra, T., Parija, S.C., Mohanty, S. (2018). "Heat shock proteins in stress in teleosts". Regulation of heat shock protein responses. Springer, 71-94.

Monteiro, D.A., Rantin, F.T., Kalinin, A.L. (2009). "The effects of selenium on oxidative stress biomarkers in the freshwater characid fish matrinxã, Brycon cephalus exposed to organophosphate insecticide Folisuper 600 $\mathrm{BR}^{\circledR}$ (methyl parathion)". Comparative Biochemistry and Physiology Part C: Toxicology \& Pharmacology, 149, 4049.

Neiffer, D.L., Stamper, M.A. (2009). "Fish sedation, anesthesia, analgesia, and euthanasia: considerations, methods, and types of drugs". ILAR journal, 50, 343-360.

Oliveira, M., Maria, V., Ahmad, I., Serafim, A., Bebianno, M., Pacheco, M., Santos, M. (2009). "Contamination assessment of a coastal lagoon (Ria de Aveiro, Portugal) using defence and damage biochemical indicators in gill of Liza aurata-an integrated biomarker approach". Environmental Pollution, 157, 959-967.

Oruç, E.Ö., Üner, N. (2000). "Combined effects of 2, 4-D and azinphosmethyl on antioxidant enzymes and lipid peroxidation in liver of Oreochromis niloticus". Comparative Biochemistry and Physiology Part C: Pharmacology, Toxicology and Endocrinology, 127, 291296.

Pakzad, H.R., Pasandi, M., Yeganeh, S., Lahijani, H.A.K. (2016). "Assessment of heavy metal enrichment in the offshore fine-grained sediments of the Caspian Sea". Environmental monitoring and assessment, 188, 303.

Pierron, F., Bourret, V., St-Cyr, J., Campbell, P.G., Bernatchez, L., Couture, P. (2009). "Transcriptional responses to environmental metal exposure in wild yellow perch (Perca flavescens) collected in lakes with differing environmental metal concentrations $(\mathrm{Cd}, \mathrm{Cu}, \mathrm{Ni}) "$. Ecotoxicology, 18, 620-631.

Raeisi, S., Sharifi Rad, J., Sharifi Rad, M., Zakariaei, H. (2014). "Analysis of heavy metals content in water, sediments and fish from the Gorgan bay, southeastern Caspian Sea, Iran". International Journal of Advanced Biological and Biomedical Research, 2, 2162-2172.

Rudneva, I.I., Kuzminova, N.S., Skuratovskaya, E.N., Kovyrshina, T.B. (2010). "Comparative study of glutathione-S-transferase activity in tissues of some Black Sea teleosts". International J. of Science and Nature, 1, 1-6.

Safari, R., Shabani, A., Ramezanpour, S., Imanpour, M., Rezvani, S. (2014). "Alternations of heat shock proteins (hsp70) gene expression in liver and gill of Persian sturgeon (Acipenser persicus Borodin, 1987) exposed to cadmium chloride". Iranian Journal of Fisheries Sciences, 13, 979-997.

Sarkar, S., Roy, S. (2017). "A mini review on heat shock proteins (HSPs): special emphasis on heat shock protein70 (HSP70)". BN Seal Journal of Science, 9, 130-139.

Srikanth, K., Ahmad, I., Rao, J.V., Trindade, T., Duarte, A.C., Pereira, E. (2014). "Modulation of glutathione and its dependent enzymes in gill cells of Anguilla anguilla exposed to silica coated iron oxide nanoparticles with or without mercury co-exposure under in vitro condition". Comparative Biochemistry and Physiology Part C: Toxicology \& Pharmacology, 162, 7-14. 
Underwood, W., Anthony, R. (2013). "AVMA Guidelines for the Euthanasia of Animals: 2020 Edition". Retrieved on March, 30, 2020-2001.

Whitley, D., Goldberg, S.P., Jordan, W.D. (1999). "Heat shock proteins: a review of the molecular chaperones". Journal of Vascular Surgery, 29, 748-751.

Yamashita, M., Yabu, T., Ojima, N. (2010). "Stress protein HSP70 in fish". Aqua-BioScience Monographs, 3, 111141.

Zhang, L., Qiu, L., Wu, H., Liu, X., You, L., Pei, D., Chen, L., Wang, Q., Zhao, J. (2012). "Expression profiles of seven glutathione S-transferase (GST) genes from Venerupis philippinarum exposed to heavy metals and benzo [a] pyrene". Comparative Biochemistry and Physiology Part C: Toxicology \& Pharmacology, 155, 517-527.

Zhang, Y., Zuiderweg, E.R. (2004). "The 70-kDa heat shock protein chaperone nucleotide-binding domain in solution unveiled as a molecular machine that can reorient its functional subdomains". Proceedings of the National Academy of Sciences of the United States of America, 101, 10272-10277. 